\title{
Pembinaan Perencanaan Pemasaran Bagi Pedagang Obat Tradisional Di Kota Batam
}

\author{
Raymond $^{1 *}$, Dian Lestari Siregar ${ }^{2}$, \\ ${ }^{1,2}$,Fakultas Ilmu Sosial Dan Humaniora \\ 1,2,Universitas Putera Batam \\ *e-mail : Raymond@puterabatam.ac.id
}

\section{Informasi Artikel}

Diterima Redaksi : 25 Maret 2021

Revisi Akhir : 12 April 2021

Diterbitkan Online : 30 Juni 2021

Kata Kunci: Pembinaan, Pemasaran, pengabdian

\begin{abstract}
Abstrak
Objek yang akan dibina dalam pengabdian kali ini adalah Toko obat aulia tiban garden merupakan UMKM yang bergerak di bidang obat-obatan. Toko obat ini bertempat di jalan Tiban garden blok C No 32 Batam, saat ini toko obat Toko obat aulia tiban garden dimiliki oleh Ibu Salmi Yanti. Toko obat aulia tiban garden menjual berbagai obat-obatan baik dari jenis tradisional. Untuk itu pengabdian masyarakat kali adalah pembinaan dalam memahami dan membuat perencanaan pemasaran usaha, metode yang digunakan dalam pengabdian masyarakat kali ini adalah pertama Tim Dosen memberikan ceramah dan pemaparan tentang teori perencanaan pemasaran usaha, kedua Peserta akan diberi Pembinaan dalam membuat perencanaan pemasaran usaha, ketiga Peserta akan diberikan kesempatan untuk mendiskusikan permasalahan yang dihadapi dalam pembuatan perencanaan pemasaran usaha. Diharapkan program pengabdian masyarakat kali ini dapat memberikan kontribusi berupa pertama Peserta termotivasi membuat perencanaan pemasaran usaha, kedua Peserta mampu terampil dalam membuat perencanaan pemasaran usaha. Berdasarkan pengabdian yang telah dilakukan maka ada beberapa manfaat yang dapat diambil diantaranya Peserta memiliki pemahaman tentang pembuatan perencanaan pemasaran, Kedua Peserta juga telah dapat memahami mengenai ruang lingkup dari perencanaan pemasaran, ketiga Peserta telah dapat membuat perencanaan pemasaran.
\end{abstract}

Dari data tersebut, terbukti bahwa UMKM juga memilki peran penting dalam membangun pondasi ekonomi Indonesia. Pada beberapa kondisi perekonomian dunia yang beberapa tahun mengalami krisis ekonomi dunia, perekonomian Indonesia berada di kondisi stabil karena diuntungkan peran UMKM yang merupakan sektor usaha yang tangguh dan fleksibel dalam menghadapi dinamika ekonomi.

Menurut Partomo, (2009) ada beberapa keunggulan yang dimiliki oleh UMKM jika dibandingkan dengan badan usaha lainnya diantaranya:

1. Inovasi dalam teknologi yang telah dengan mudah terjadi dalam pengembangan produk. 
2. Hubungan kemanusiaan yang akrab didalam perusahaan kecil.

3. Kemampuan menciptakan kesempatan kerja cukup banyak atau penyerapannya terhadap tenaga kerja.

4. Fleksibilitas dan kemampuan menyesuaikan diri terhadap kondisi pasar yang berubah dengan cepat dibanding dengan perusahaan skala besar yang pada umumnya birokratis.

5. Terdapatnya dinamisme managerial dan peranan kewirausahaan.

Namun banyak UMKM gagal dalam proses awal pengoperasionalannya, salah satunya alasan gagalnya UMKM tersebut adalah kurangnya pemahaman UMKM terhadap perencanaan pemasaran. Perencanaan pemasaran adalah suatu bagan dari suatu desain untuk mencapai suatu tujuan. Tujuannya adalah untuk menciptakan nilai bagi konsumen dalam kondisi tetap menguntungkan perusahaan, atau dalam konsep pemasaran saat ini, suatu hubungan yang saling menguntungkan.

Objek yang akan menjadi sasaran dalam pengabdian ini adalah para pedagang Toko obat tradisional dikota Batam, salah satunya adalah Toko obat aulia tiban garden yang merupakan UMKM yang bergerak di bidang obat-obatan. Toko obat ini bertempat di jalan Tiban garden blok C No 32 Batam, saat ini toko obat Toko obat aulia tiban garden dimiliki oleh Ibu Salmi Yanti. Toko obat aulia tiban garden menjual berbagai obat-obatan baik dari jenis tradisional maupun obat dari resep dokter

Dalam menjual produknya Toko obat Aulia Tiban Garden masih dilakukan dengan cara tatap muka langsung, dimana konsumen langsung mendatangi tempat penjual untuk membeli produk. Hal tersebut juga menjadi kendala untuk konsumen yang jauh harus membutuhkan waktu, tenaga dan mengeluarkan biaya lebih besar untuk mendapatkan produk yang dibutuhkan, selain itu menjamurnya apotik juga turut mengancam keberlangsungan pedagang Toko obat tradisional di kota batam. Untuk itu diperlukanlah suatu pembinaan dalam memahami dan membuat Perencanaan tentang pemasaran bagi pedagang Toko obat tradisional

\section{METODE}

Untuk memperoleh manfaat dari pengabdian ini serta dapat diimplementasikan, maka metode yang ditawarkan dalam pengabdian ini adalah sebagai berikut:

1. Langkah 1 (Metode ceramah)

Tim Dosen memberikan ceramah dan pemaparan tentang teori Perencanaan pemasaran

2. Langkah 2 (Metode Tutorial)

Peserta akan diberi Pembinaan dalam membuat Perencanaan pemasaran mulai dari biaya investasi sampai dengan analisis sosial ekonomi

3. Langkah 3 (Metode diskusi)

Peserta akan diberikan kesempatan untuk mendiskusikan permasalahan yang dihadapi dalam pembuatan Perencanaan pemasaran.

Kegiatan Pembinaan bagi pedagang Toko obat tradisional di kota Batam ini akan dievaluasi agar diketahui seberapa jauh keberhasilan dari kegiatan pembinaan ini, berikut disajikan tabel 1 evaluasi dalam Pembinaan Perencanaan pemasaran ini :

Tabel 1. Tabel evaluasi

\begin{tabular}{ll}
\hline Tujuan & $\begin{array}{l}\text { Indikator } \\
\text { ketercapaian }\end{array}$ \\
\hline Peserta termotivasi & $\begin{array}{l}\text { Peserta mau } \\
\text { Membuat } \\
\text { membuat }\end{array}$ \\
Perencanaan & Perencanaan \\
pemasaran & pemasaran \\
\hline Peserta mampu & Peserta mampu \\
terampil dalam & membuat beberapa \\
membuat & aspek dalam \\
Perencanaan & Perencanaan \\
pemasaran & pemasaran \\
\hline
\end{tabular}

\section{HASIL DAN PEMBAHASAN}

\subsection{Persiapan}

Berdasarkan pembinaan yang telah dilakukan bagi Pedagang obat tradisional di kota Batam diharapakan dapat memberikan dampak yang positif kepada para peserta itu sendiri dan juga kepada tim dosen yang melakukan pembinaan, atau secara rinci hasil yang ingin dicapai dari persiapan pelaksanaan pembinaan tersebut dapat diuraikan antara lain adalah sebagai berikut:

1. Terjalinnya kerja sama antara Universistas Putera Batam dengan masyarakat luar. 
2. Dapat menambah wawasan tersendiri dari saya pribadi dan rekan tim dosen yang lain dalam hal pemahaman tentang Studi kelayakan bisnis

3. Menambah wawasan dan pengetahuan bagi peserta Pembinaan itu sendiri (Pedagang obat tradisional) dalam membuat sebuah perencanaan pemasaran.

4. Dapat mengembangkan serta berbagi ilmu pengetahuan ke setiap lapisan masyarakat yang ada, termasuk dalam hal ini adalah Pedagang obat tradisional.

\subsection{Pelaksanaan}

Adapun Kegiatan pembinaan perencanaan pemasaran bagi Pedagang obat tradisional dilaksanakan selama tiga tahap pertemuan. Adapun susunan acara pembinaan sebagai berikut:

Tabel 2. Kegiatan pengabdian

\begin{tabular}{|c|c|}
\hline Kegiatan & $\begin{array}{c}\text { Tim } \\
\text { Pengabdi }\end{array}$ \\
\hline $\begin{array}{l}\text { Pembukaan dan } \\
\text { kata sambuatan } \\
\text { dari Pengabdi }\end{array}$ & Ketua \\
\hline $\begin{array}{l}\text { Sambutan dari } \\
\text { Peserta pembinaan } \\
\text { perencanaan } \\
\text { pemasaran }\end{array}$ & Ibu Salmi yanti \\
\hline $\begin{array}{l}\text { Acara Inti: } \\
\text { Memberikan } \\
\text { pemahaman materi } \\
\text { tentang Cara } \\
\text { menyusun } \\
\text { perencanaan } \\
\text { pemasaran }\end{array}$ & $\begin{array}{l}\text { Ketua dan } \\
\text { anggota }\end{array}$ \\
\hline Penutup & Ketua \\
\hline
\end{tabular}

Pelaksanaan pembinaan dibagi dalam tiga tahap selama tiga kali pertemuan. Pada pertemuan pertama dilaksanakan pada hari Minggu, 11 Juni 2017 pukul 13.00 sampai dengan 15.30 diawali dengan pembukaan serta sambutan yang disampaikan oleh Ketua Pengabdi dan Ibu salmi yanti dan langsung dilanjutkan pada penyampaian materi pertama oleh Ketua dan anggota pengabdi dengan topik gambaran umum tentang perencanaan pemasaran.

Pembinaan hari kedua dilaksanakan pada hari Minggu, 30 Juni 2017 pukul 13.00 sampai dengan 16.45. Materi disampaiakan secara bergantian yang dimulai oleh Ketua dan anggota Pengabdi dengan topik Aspek aspek dalam perencanaan pemasaran. Kegiatan penyampaian materi berlangsung selama kurang lebih tiga setengah jam dengan durasi penyampaian setiap materi adalah selama 30 menit per pemateri.

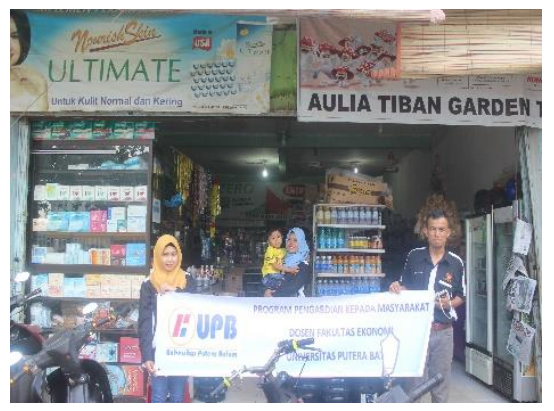

Gambar 1. Kegiatan pengabdian

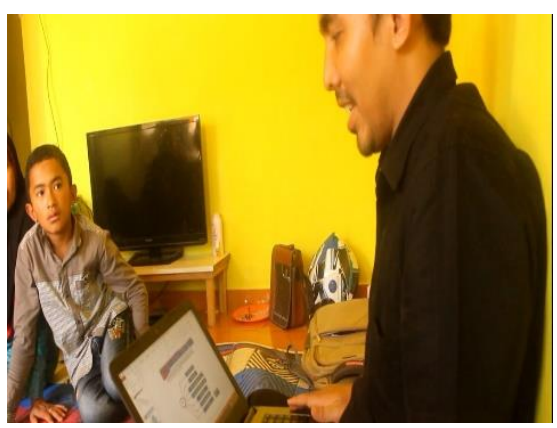

Gambar 2. Kegiatan pengabdian

Pembinaan Ketiga dilaksanakan pada hari Minggu, 25 Juni 2017 pukul 13.00 sampai dengan 16.45. Materi disampaiakan secara bergantian yang dimulai oleh Ketua dan anggota Pengabdi dengan topik pembuatan laporan perencanaan pemasaran. Kegiatan penyampaian materi berlangsung selama kurang lebih tiga setengah jam yang diakhiri penutupan yang disampai ketua pengabdi.

Dari keseluruhan pertemuan pengabdian dari pertemuan satu hingga ketiga disimpulkan bahwa para peserta sudah memahami cara membuat perencanaan pemasaran, hal ini berbeda dengan pertemuan pertama dimana para peserta menganggap perencanaan pemasaran adalah sesuatu yang rumit, susah, merepotkan, dan menghabiskan waktu. Hingga setelah tim pengabdi menyampaian pembinaan hal tersebut secara berangsur angsur berubah dimana Peserta sangat 
antusias ingin membuat perencanaan pemasaran untuk usaha mereka.

\subsection{Evaluasi}

Berdasarkan hasil Pembinaan kepada pedagang obat tradisional, saya bersama Tim telah melakukan beberapa hal yang mana dari hasil pembinaan tersebut pedagang obat tradisional dapat membuat perencanaan pemasaran sendiri. secara garis besar hasil pembinaan ini dapat dijelaskan sebagai berikut, Pelaksanaan pembinaan yang dilaksanakan 3 kali pertemuan dimana materi yang disampaikan adalah menyampaikan mengenai gambaran umum perencanaan pemasaran, materi ini membahas tentang pengenalan mengenai perencanaan pemasaran, pemateri menyampaikan pentingnya perencanaan pemasaran bagi usaha kecil dan pembuatan laporan perencanaan pemasaran. Peserta pada saat itu belum mengerti mengenai perencanaan pemasaran dan fungsi perencanaan pemasaran. Hingga dilanjutkan pada pertemuan terakhir mengenai pembuatan laporan perencanaan pemasaran, setelah itu barulah peserta mulai memiliki bayangan dan gambaran terhadap apa itu perencanaan pemasaran dan tata cara menyusunnya. Pemberian pembinaan ini juga meliputi membina kemampuan para perserta secara bertahap dalam membuat laporan perencanaan pemasaran, sehingga para peserta tahu dan memahami bentuk dari laporan perencanaan pemasaran.

\section{KESIMPULAN}

Berikut adalah beberapa kesimpulan yang dapat diambil berdasarkan kegiatan pengabdian (Pembinaan) yang telah dilakukan, diantara adalah sebagai berikut:

1. Peserta memiliki pemahaman tentang pembuatan perencanaan pemasaran.

2. Peserta juga telah dapat memahami mengenai ruang lingkup dari perencanaan pemasaran

3. Peserta telah dapat membuat perencanaan pemasaran

\section{SARAN}

Berikut adalah beberapa saran yang dianggap perlu berdasarkan kegiatan pengabdian (pelatihan) yang telah dilakukan sebagai berikut:

1. Sebaiknya penyuluhan dan diskusi seperti ini dilaksanakan secara berkala.

2. Sebaiknya semua peserta sudah hadir tepat waktu (sebelum acara dimulai) jadi tidak ada peserta yang datang diawal, ditengah atau bahkan diakhir acara sehingga materi yang disampaikan tidak diulang-ulang.

4. Kedepan jumlah Peserta yang mengikuti Pembinaan perencanaan pemasaran

5. bisa meningkat sehingga dengan adanya pelatihan ini diharapkan dapat membantu UMKM dalam menangani berbagai permasalahan Khusunya yang berkaitan dengan pembuatan perencanaan pemasaran.

\section{UCAPAN TERIMA KASIH}

Ucapan terima kasih ditujukan Universitas Putera Batam melalui LPPM UPB Yang telah memfasilitasi pelaksanaan pengabdian ini. Ucapan terima kasih juga disampaikan kepada Ibu Salmi Yanti selaku pihak yang membantu pelaksanaan PKM ini menjadi sukses.

\section{REFERENSI}

[1] BPS. 2014. Batam dalam Angka. Batam: BPS.

[2] Partomo, T.S. (2004). Usaha kecil dan menengah dan koperasi.Working paper series No.9.center for industry and SMEs Studies. Faculty of economics. University of Trisakti 